\title{
食欲と内在性有機化合物
}

\author{
大 村 \\ 裕*

\section{Endogenous Organic Chemical Substances and Food Intake Regulation.}

Yutaka OOMURA*

\begin{abstract}
The regulation of food intake is conducted by the feeding and satiety centers in the hypothalamus, part of the brain. Blood born materials such as glucose, insulin, free fatty acids, and glucagon, which are related to metabolism, are known to be involved in the induction of hunger or satiety. Behavior and electrophysiological experiments have shown that these and other humoral factors act as hunger and satiety signals, through the chemosensitive neurons located in the two centers. To identify other blood factors that might affect body weight by controlling feeding, blood from rats in various stages of food deprivation was analyzed for its constituents. Two short chain sugar acids, 3,4-dihydroxybutanoic acid (2-deoxytetronic acid, 2-DTA) and 2,4,5-trihydroxypentanoic acid (3-deoxypentonic acid, 3-DPA), were isolated by a gas chromatograph-mass spectrometercomputer system. Their effects on rat feeding behavior and on neuron activity were investigated. Injections of 2-DTA into the rat third cerebral ventricle suppressed food intake. The same amounts of 3-DPA elicited feeding. The activity of chemosensitive neurons was suppressed by 2-DTA in the feeding center and facilitated in the satiety center. The effect of 3-DPA was just opposite on the neurons in these two centers. High correlation between modulation of feeding behavior and changes in chemosensitive neuron activity suggested that 2-DTA may act as an endogenous satiety substance and 3DPA as a hunger substance. The effect of 3-hydroxybutyric acid and other related substances were also verified and discussed.
\end{abstract}

\section{1. いとぐち}

食欲の調節一食欲は脳の活動である。脳でも一番大き く関与している部位は視床下部である。視床下部を考え る場合, ハードウェアとしての部分つまり神経回路と, それを動かすソフトウェアとしての体液性の化学物質の 2 要素が必要となる。視床下部には摄食中枢と満腹中枢 があり，相互にブレーキを掛け合っているような仕組で ある。体液性の化学物質は大きく分けて 2 種類で, 一ゅ は捸食中枢を刺激してその活動を高めると同時に満腹中 枢に作用してその活動を抑制する。他はその逆である。 前者は食欲高進につながる空腹物質であり, 後者は食欲

* 九州大学医学部生理学教室

* Kyushu University, Faculty of Medicine
抑制に働く満腹物質である。重症の病人は食欲不振に悩 むが，空腹物質によって食欲を出させることがいかに患 者を勇気付けることになるか, この気持の高揚は視床下 部一内分泌系をより活性化し症状の改善をむたらし, そ れはまた再びこの系に作用するといら正のフィードバッ クとして働くことになる。また肥満患者の食欲を抑制す ることは高血圧の低下, 内分泌系の改善, 血中コレステ ロール, 糖, 遊離脂肪酸, 電解質などの改善につながる。 このことから心筋梗塞, 糖尿病, 腎臟病などの成人病の 予防に発展することになる。つまり内在性の食欲調節物 質の探索, これが人類の幸福に寄与することになる。言 葉をかえると有機合成と神経生理の学際的共同研究, こ れが一番大切なことである。

\section{2. 満腹中枢と摂食中枢}

満腹中枢の発見は第 2 次大戦の初期で臨床での小さな 
観察からである。リュウマチ患者に金療法をしていた場合 応々にして肥満が起こってくる。下に示すように金といっ てもグルコースに硫黄一金のついたものである。この患者の 脳の組織的検索から，視床下部腹内側核 (Ventromedial nucleus of hypothalamus (VMH))のニューロンが破 壊されていることが見出された。シカゴのノースウエス

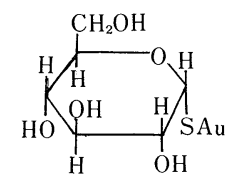

タン大学の神経解剖学者ランソンがそれに目をつけて, ラット，ネコなどで実際に針状の電極を脳の上から深部 にある VMHに刺入して, 電極に直流通電して VMH だけを限局して破壊し, 過食による肥満を証明した。破 壊後 5 週間で体重が 1.8 倍にも増加している（対照はわ ずか 1.1 倍)。ついで破壊の代りに, 電極を通して $60 \mathrm{~Hz}$ のパルスで $\mathrm{VMH}$ を刺激してみると, 飰を摂っている最 中でも摂食行動を停止することを確かめた。

摂食中枢の発見も偶然である。戦後エール大学の神経 生理学教室のフルトンのもとにインドから留学していた アナンドとアメリカ人のブロベックが VMH 破壊実験を 追試していたとき，全然餌を摂らず放置しておけば餓死 する動物が出てきた。VMH の直径は約 $1 \mathrm{~mm}$ で，そこ を破壊することはそう容易ではないが調べてみると VMH は健常でそれから $1.5 \mathrm{~mm}$ 外側のやはり直径 $1 \mathrm{~mm}$ の外 側野(lateral hypothalamic area(LHA))が破壊を受け ていた。これが捸食中枢で満腹中枢の発見から 10 年目 （1952 年）であった。LHA は電気的に刺激すると満腹 の動物でも餌を求めて食べる。餌を普段あるところでな く,つい立の後ろに穏しておいてもわざわざそこまで行 って食べるという合目的な行動をする。これは大脳皮質 の前頭前野にある連合野と LHA が直接接続しているか ら前頭前野でうまく判断してできる行動である。このよ うに満腹中枢と摄食中枢はシーソーゲームのように相反 的に活動している。

こうして摄食調節は 2 中枢の相反的活動が基本的なも のとであるという考えが大勢を占めてきていた。1960年 後半から 1970 年前半になり，スウェーデンの神経解剖 学者達がノルアドレナリン系, ドーパミン系, セロトニ ン系などのニューロンの細胞体およびそれから出て行く 神経線維系を組織学的にうまく見出すホルマリン蒸気法 （切片をホルマリン蒸気で処置した後蛍光顕微鏡でみる） を新しく開発した。両中枢には内側前脳束および室周線 維束という線維群がそれぞれ通過しており，上位中枢と
下位神経機構とを連絡している。この方法で観察すると 2 線維系には上記の系が含まれている。したがって例えば LHA 破壊で当然内側前脳束も破壊される。破壊の効果 は中枢自身の機能喪失というよりノルアドレナリン系, ドーパミン系, セロトニン系などの破壊効果であろうと いう考えが強くなってきた。ところが 1970 年後半から ニューロンの細胞体だけを破壊し通過線維は無傷のまま というカイニン酸法が開発された。グルタミン酸はニュ ーロン細胞体に非特異的に作用する。一般的には興奮作<smiles>NC(CC(=O)O)C(=O)O</smiles>

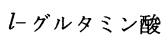<smiles>C=C(C)C1CNC(C(=O)O)C1CC(=O)O</smiles>

カイニン酸<smiles>NC(C=O)c1cc(O)no1</smiles>

イボテン酸

用であるが 5 員環をもつカイニン酸はグルタミン酸のア ゴニストと考えられている。カイニン酸より毒性や副作 用の少ないイボテン酸も用いられている。1980 年前半に カイニン酸を微少量 LHA に注入しても古典的な全体破 壊の場合と同様の症状を呈することがシカゴ大学のグロ スマンらによって証明され, 再び 2 中枢のニューロン群 が捸食調節の基本であることが明らかになった。我々も イボテン酸をラットの $\mathrm{VMH}$ に微少量注入すると, 過食 と肥満が発生することを証明できた。

\section{3. 化学感受性ニューロン}

満腹および掞食中枢の人工的電気的刺激に代わりうる 脳内での自然の刺激は何であろうか。これが本題の内在 性化学物質で, いわゆる血中にある満腹あるいは空腹物 質である。両中枢内のどのようなニューロンがこれら化 学物質に反応するのであろうか。

3. 1. 満腹中枢内のブドウ糖受容ニューロン $\mathrm{VMH}$ はラット, ネコ, アカゲザルなどでは直径 $1 \mathrm{~mm}$ でその 内に約 2 万個のニューロンが存在する。そのうち約 $1 / 4$ がブドウ糖によって活動が上昇するブドウ糖受容ニュー ロンである。微少量のブドウ糖溶液 $(0.1 \mathrm{M} \mathrm{NaCl}$ 液に $0.4 \mathrm{M})$ を多連微小電極法でニューロンに投与すると活動 上昇するもので同濃度のショ糖液，果糖液などでは影響 
しない。通常活動上昇をきたすブドウ糖濃量は $10^{-13} \mathrm{~mol}$ でニューロン周囲での濃度は約 $2 \mathrm{mM}$ である。受容器が あるという根拠は（1） $\alpha$-メチルブドウ糖および $\beta$-メ チルブドウ糖に対して,ブドウ糖と同様に量一反応的に反 応するが， $\beta$ 型がより低濃度で有効，（2）フロリジンは 大分子のフロレチンに $\beta$-ブドウ糖が結合している。こ れはブドウ糖受容器と結合するが細胞内には入らないと 考えられる。事実ブドウ糖と同様の作用をもっている。 ( 3 ）ブドウ糖受容ニューロンの受容器は特殊な蛋白構 造をもつと考えられる。したがって特異的な抗体が得ら れるはずである。ラット VMH のホモジネートから得 た抗体は，共通のラット脳や血清に対する抗体も含むの でそれらを吸収した後でも，VMH ホモジネートと特殊 な沈降線を作成する。この抗体を多連微小電極法で $\mathrm{VMH}$ ニューロンに投与すると，ブドウ糖ニューロンだ けが特異的に反応して障害を受ける。ブドウ糖受容ニュ 一ロンがブドウ糖によって活動上昇を起こす原因は，ブド ウ糖が受容器につくとニューロン膜の Kイオンの通過する Kチャンネルが閉じるため $\mathrm{K} イ$ オンの通過が不充分となる ためである。すなわち膜の電気的抵抗増大一細胞が脱分 極を起こす一活動電位が発生するという順序である。K チャンネルの閉じることは，セロトニンがセロトニン受容器 に結合した場合に起こる現象と同じである。この場合は膜 のアデニール酸シクラーゼが活性化して細胞内のサイクリ ック AMP 濃度が上昇する一蛋白キナーゼAを活性化す る—この酵素がKチャンネル蛋白をリン酸化し形を変化 させる—チャンネルが閉じる1)。ブドウ糖の場合も同 様の課程が起こるかどうか, 現在実験中である。

3. 2. 摂食中枢内のブドウ糖感受性ニューロン LHA 内のニューロンの約 $1 / 4$ は, ニューロン周囲の ブドウ糖濃度が $2 \mathrm{mM}$ 上昇すると, その活動が抑制され るブドウ糖感受性ニューロンである。このことは満腹中 枢内のブドウ糖受容ニューロンとは全く逆の機能である。 ブドウ糖による抑制作用は, 次のようである。過㮃のブ ドウ糖が細胞内に取り込まれて代謝される一その過程 で ATP が産生される—ATP が膜にある Na-K ATP ase に利用される—余分に細胞内 Naイオンが追出さ れる一Na ポンプの活性化—カチオンが出るため細胞 内はよりマイナス, つまりニューロン膜電位は過分極に なる一膜の電気的抵抗変化なし $\longrightarrow$ ニューン活動が抑 制。したがって Na-K ATP ase の活性を抑制するウア バイン（強心配糖体）をあらかじめニューロンに作用さ せておいてブドウ糖を投与すると，ニューロンに対する ブドウ糖の抑制効果は発現しない。脳内のどのニューロ ンもブドウ糖を代謝しているが，ブドウ糖に対し無反応
である，LHA のブドウ糖感受性ニューロンはその意味 で, 細胞内のエネルギー貯蔵に余有なくフル回転してい る細胞であろう。

\section{4. 摂食調節に関与する内在性物質}

VMH と LHA にそれぞれ存在するブドウ糖受容およ びブドウ糖感受性ニューロンが満腹時や空腹時に血中に増 減するホルモンや血中代謝産物に反応して, ニューロン活動 を変化させる。これが搨食の停止や誘起の引き金となって いる。この種のニューロンを化学ニューロンと総称する と, これは血中の一種類の化学物質に応ずるのではなく 複数のものに反応して活動を変化させるのである。この 変化が化学情報として VMH および LHA が直接接続し ている前頭前野にある連合野に送られて，ここではじめ て動物の行動発現となるわけである。この意味で両種の ニューロンは血液化学モニターシステムを構成する要素 である。

動物が餌を掑って満腹し，また空腹になって餌をとる 一連の期間, 経時的に採血して血中物質の変動を定量し たものを図 1 に示している。これはラットからのデータで あるが摂食開始後 10 分で一応満腹して停止している。こ れら物質はすべて摄食を調節している。捸食停止時血糖 值は約 $8 \mathrm{mM}$ と増加しているから満腹の一要因になる。 しかし脳で消費されるエネルギー源は正常ではブドウ糖 だけであり, 空腹時といっても決して低血糖にはならな いから LHA のブドウ糖感受性ニューロンの活動を高め るには別の物質を考えなければならない。

4. 1. グルカゴン これは摄食中に増加し, 摂食停 止時にピークになっていて満腹物質の可能性があり事実 そうである。グルカゴンは, 多連微小電極法でニューロン に投与するとブドウ糖感受性ニューロンだけに抑制的に 作用する。その濃度量は約 $1.7 \times 10^{-15} \mathrm{~mol}$ である。ブドウ 糖作用の場合と同じくニューロンに過分極を引き起こす が，ウアバインをこのニューロンにあらかじめ投与しな がらグルカゴンを投与すると，この抑制作用はブロック される。したがってグルカゴンの作用機序はブドウ糖と 同じく, Naーポンプの活性化である。グルカゴンはアデ ニール酸シクラーゼを活性化してサイクリック AMP を 増加させるがこれが Na-K ATP ase 活性を高進させる のである。グルカゴンはブドウ糖受容ニューロンも抑制 するがその濃度は LHA の場合の 2.5 倍である。大脳の 皮質などのニューロンにはグルカゴンは無効果である。

グルカゴンを第 3 脳室に注入すると $5 \mathrm{ng}$ の微少量で 摂食を抑制する。ラットの脳質内の脳脊髄液量は $300 \mu 1$ なので投与量は約 $15 \mathrm{ng} / \mathrm{ml}$ である。脳室内から脳実質 


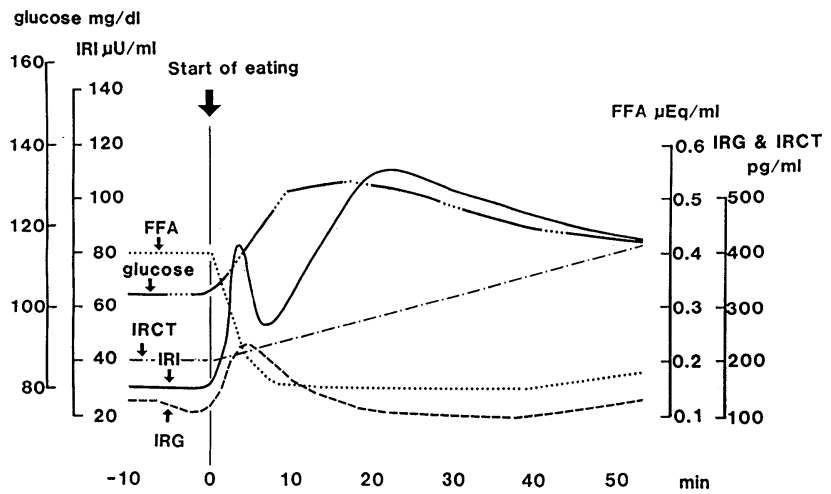

Fig. 1 Variation of rat plasma metabolites and hormones in time relative to a meal. At the very beginnig of meal free fatty acid(FFA) decreases rapidly while insulin (IRI) and glucagon (IRG) rice fairy rapidly. Glucose level rises gradually. A short time later, as glucose continues to rise, insulin drops sharply and transiently. Glucagon returns gradually to its baseline level. Insulin again rises and its level then continues to run parallel to the glucose level, while FFA and glucagon remain at their intermeal levels. Calcitonin (IRCT) also increases after meal. Abscissa :60 min.

への移行は注入後 20 分で約 $1 \%$ であるから $150 \mathrm{pg} / \mathrm{ml}$ が LHA のブドウ糖感受性ニューロンに作用したことにな り，血中濃度に比較できる生理的濃度である。

$$
\text { グルカゴンはすべて膵藏のランゲルハンス島にあるA細胞 }
$$
から分泌され，上記に使用したものも膵グルカゴンである。 ところが視床下部に存在するものは膵グルカゴン（抗体 OAL-123 で検出できる) を含むそれよりずっと大きなグ リセンチンである（抗体 GA-10, 11-15 のN端に特異的 ; 抗体 R-4804, 49-69 の C 端に特異的。この 2 抗体で検 出できる)。VMH と LHA には R-4804 で測定するとそ れぞれ $40 \mathrm{ng} / \mathrm{mg}$ 蛋白と $4 \mathrm{ng} / \mathrm{mg}$ 蛋白存在している。 24 時間掑食で $\mathrm{VMH}$ での量はわずか $18 \%$ 増加するにすぎ

$$
\begin{gathered}
\frac{1}{\text { Glucagon related pancreatic peptide - Lys- }} \\
\hline 33 \quad 61 \\
\text { Arg- Glucagon - Lys-Arg }- \text { Hexapeptide } \\
\text { ブターグリセンチン }
\end{gathered}
$$

ないがLHA で3倍と増加している。グリセンチンが LHA ニューロンにグルカゴンと同様に作用するかどうか実験 すべきであるが，まだ日本では合成されていないので入 手できない状態である。

4. 2. カルチトニン グルカゴンと同様摂食によっ て血中に 2 倍以上に増加する。これは摂食によって血中

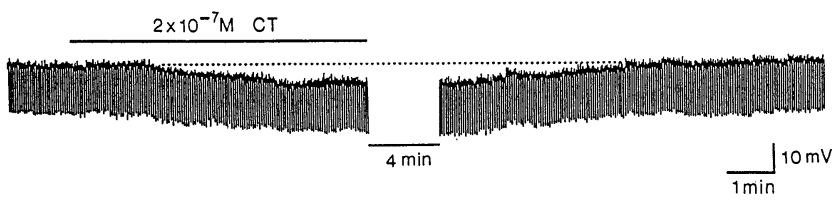

Fig. 2 Inhibitory effect of calcitonin (CT) on rat LHA glucose-sensitive neuron. Brain slice in vitro experiment. Intracellular recording. CT is applied into bathing solution. Continuous pen record of hyperpolarizing effect by CT $\left(2 \times 10^{-7} \mathrm{M}\right)$. Downward deflections, membrane response to hyperpolarizing current pulse ( $125 \mathrm{~ms}, 0.16 \mathrm{nA}$ ). Deflections indicate changes in membrane resistance. Hyperpolarization of neuron membrane by $7 \mathrm{mV}$ after application of CT and increase in membrane resistance. Original resting membrane potential, $-62 \mathrm{mV}$. Dotted line, original membrane potential (Shimizu \& Oomura, Brain Res., 1986 in press). 
に増加した Ca イオンを骨に沈着させるために甲状腺か ら分泌される。カルチトニンも視床下部に存在している が VMHには分布していない。カルチトニンを多連微小 電極法で投与すると LHA のブドウ糖感受性ニューロン
だけに作用して活動を抑制する。この抑制はニューロンの 膜電位を過分極にすることによるが，これは膜の Na チ ヤンネルや Ca チャンネルが閉じたためである（図 2 )。 寸なわち普段細胞内に流入していたカチオンが入りにくくな

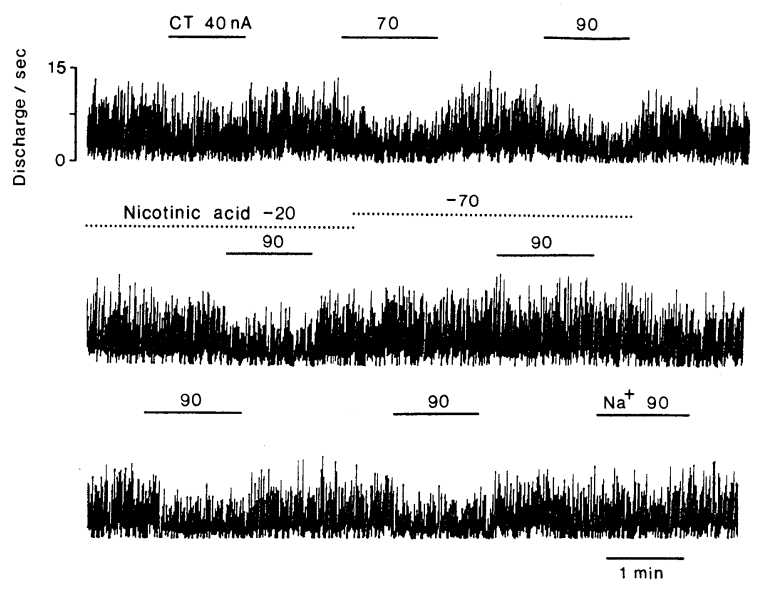

A.

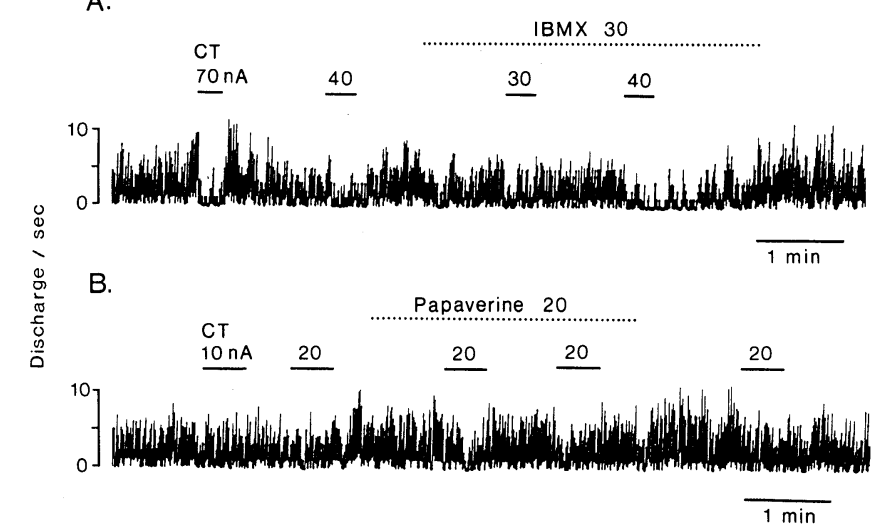

Fig. 3 Inhibitory effect of calcitonin (CT) on rat lateral hypothalamic glucosesensitive neuron. Electrophoretic application of CT. Upper most :

Extracellular recording. Dose-dependent inhibition by CT. Ordinate, discharge rate of single neuron. Bars above traces, periods of application of indicated substances at current specified by arabic numeral (nA). Upper : Blockade of inhibitory response to CT by nicotinic acid. Continuous record from upper to lower. During electrophoretic application of a low dose of nicotinic acid $(-20 \mathrm{nA})$, inhibitory action of CT is attenuated. High dose of nicotinic acid $(-70 \mathrm{nA})$ blocks response completely (middle trace). Partial recovery in lower trace. $\mathrm{Na}^{+}$had no effect, indicating no current or osmotic effects. Lower : Augmentation of CT . response by phosphodiesterase inhibitors. Simultaneous application of 3-isobutyl-1-methylxanthine (IBMX) or papaverine through another pipettes. Threshold application of CT ( $40 \mathrm{nA})$ decreases firing rate slightly; marked and prolonged inhibition of discharge rate produced by IBMX (30 nA, dotted line). Lowest : Different neuron. Appearance of CT response (20 nA) by simultaneous application of paraverine (20 nA) (Shimizu \& Oomura, Brain Res., 1986 in press). 
るため細胞内はより負になるのである。このチャンネ ルの閉じることも, カルチトニンによる膜のアデニール 酸シクラーゼの活性 一細胞内サイクリック AMP の増 加一蛋白キナーゼ $\mathrm{A}$ の活性化 $\longrightarrow \mathrm{Na}$ あるいは $\mathrm{Ca}$ チャ ンネル蛋白のリン酸化によるチャンネル閉塞というもの であろう。それは（1）アデニル酸シクラーゼの活性を 抑えるニコチン酸をあらかじめブドウ糖感受性ニューロ ンに投与しながらカルチトニンを投与してもこの抑制が 起こらない(図 3A)。(2) サイクリック AMP の分解 をブロックするイソブチルメチルキサンチンやパパベリ ンをあらかじめ投与しながらカルチトニンを投与すると この抑制効果が増強してくる (図 3B), この 2 点からで ある。実際に第 3 脳室内に $30 \mu \mathrm{g}$ 注入すると摂食抑制が 起こるがこの濃度は 4. 1. で述べたように計算するとLHA へは約 $1 \mathrm{ng} / \mathrm{ml}$ となる。ラットの場合カルチトニン量はデ ータによって大きく変化している(図 1 では $200 \mathrm{pg} / \mathrm{ml}$ )。 あるデータではオスで血中に $7 \mu \mathrm{g} / \mathrm{ml}$, メスで $34 \mu \mathrm{g} / \mathrm{ml}$ である。

4. 3. 他のペプチド＼cjkstart脳内にあるニューロペプチド $\mathrm{Y}$ ，パンクレアチックポリペプチドなどは脳室内や視床 下部室傍核に投与すると搨食高進をきたすことがわかって いるが，どこに作用するのか，どのような作用機序によ るかなど全然不明である。

\section{5. 有 機 酸}

図 1 に示すように捸食によって空腹時高濃度であった 遊離脂肪酸 (FFA) は低下寸る。これは捸食によって血 中に増加したブドウ糖とインスリンによって, 脂肪細胞に FFA を取り込んでの脂肪合成が促進されたためである。 したがって FFA が空腹物質である可能性が考えられる。 FFA を抽出して多連微小電極法で投与するとブドウ糖 受容ニューロンを抑制し, ブドウ糖感受性ニューロンを 促進する。FFA の一成分であるパルミチン酸やオレイ ン酸でも同様である。

血中には FFA 以外にも同様のC鎖の物質が空腹時に 存在する可能性があるので新しい有機酸を探索する目的 で次の実験を行った。

5. 1. 新しい摂食調節有機酸 ラットを絶食させて, 12 時間おきに採取し GC/MS で検討してみた。これには 当時久留米大学医学部ガスマスセンターの松本 勇助教 授および久原とみ子講師にお願いした。FFA，ケトン体 (3-hydroxybutyric acid, acetoacetate など) など多く の物質が検出できたが，その内で新しく，しかも短 C鎖で 化学構造が簡単で比較的容易に合成できそうな物質を 3 種選出しその生理作用を調べてみた。3,4-dihydroxy-

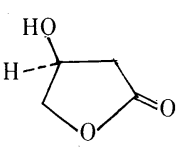

$S$ 型

2-DTA<smiles>O=C1OCCC1O</smiles>

$S$ 型

3-DTA

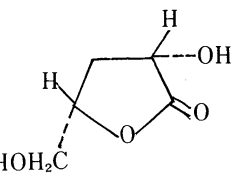

$2 S-4 S$ 型

3-DPA butanoic acid (2-deoxytetronic acid, 2-DTA), 2,4dihydroxybutanoic acid (3-deoxytetronic acid, 3DTA) および 2,4,5-trihydroxypentanonic acid (3-deoxypentonic acid，3-DPA) である2)。2-DTA は不斉 炭素は 1 個，また 3-DPA は 2 個ある。九大理学部 奥門信久助教授は 2-DTA の $S, R$ 型 2 種と, 3-DPAの $2 S, 4 S ; 2 S, 4 R ; 2 R 4 \mathrm{~S} ; 2 R 4 R$ の 4 種を合成した。 また九大薬学部の酒井 浄教授は 2-DTA の $\mathrm{S}$ 型を合成 した。結局は化学構造に示すように 2-DTA では $S$ 型, 3-DPA では $2 S, 4 S$ 型だけが有効である。またこれら は血中ではラクトン環として存在し, 3-DPA は $2 S, 4 S$ 型で存在している。血中濃度も約 $0.1 \mathrm{mM}$ であり, FFA の約 $0.3 \mathrm{mM}$ 濃度に近い。絶食によって最初 3-DPA が 増加し 36 時間でピークになるがついで 2-DTA が増加 してくる。

5. 1. 1. ラット摂食に対する効果 これら物質を $1.2 \sim$ $2.5 \mu \mathrm{mol}$ 第 3 脳質内に注入すると, それぞれ効果が出て くる。ラットは夜間消灯後慨を 1 日量の大部分摂食し, 昼間はときどきわずかしか食べない。図4左に示すよう に2-DTA を消灯直後に注入すると, 夜間の摂食量は 約 $1 / 2$ に低下寸る。ラットの歩行量はそう低下しないし， 5. 1. 2. で述べるようにVMH と LHA のニューロンにし か作用しないから，摂食量の低下は大脳皮質などに対す る一般的な抑制作用ではない。この攝食抑制効果は 72 時間絶食ラットにも有効で相当な効力である。図 4 右に 示すように，3-DPA は尽間に注入すると 10 分後に摂食 を誘起し，ラットの 1 回量を摄取する。脳室内への有効 濃度は 4. 1. に述べたように計算すると $4 \sim 8 \mathrm{mM} \rightarrow$ 脳実 質へは $40 \sim 80 \mu \mathrm{M}$ となって，血中濃度に近く生理的で ある。3-DPA とほとんど同様の摂食誘起作用を 3-DTA がもっている。

5. 1. 2. VMH および LHA ニューロンに対する作用 ${ }^{2,3)}$

多連微小電極法で 2-DTA と 3-DPA をニューロンに 作用させてみると, 両者とも VMH のブドウ糖受容二ュ ーロンと LHA のブドウ糖感受性ニューロンにだけ有効 である。すなわち 2-DTA はブドウ糖受容ニューロンの活 動を上昇し，ブドウ糖感受性ニューロン活動を抑制する。 この抑制効果は，あらかじめウアバインを投与しながら 2-DTA を作用させるとブロックされる。ブドウ糖受容 
A
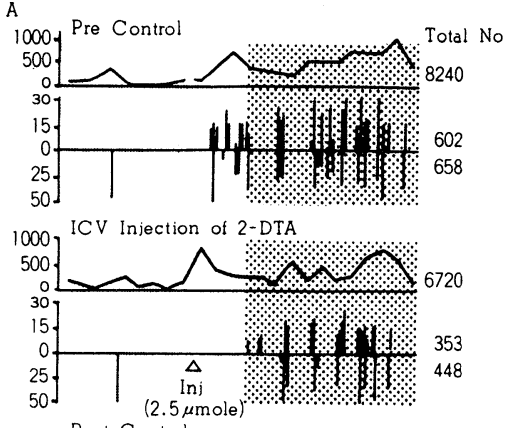

1000 Post Control

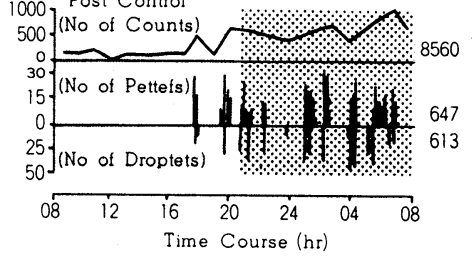

B 1600 Pre Control Total No
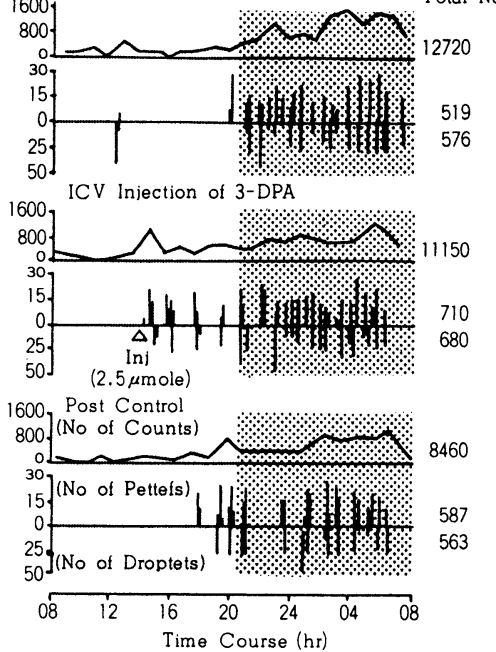

Fig. 4 Effects of intra-third cerebral ventricular (icv) injection of satiety and hunger substances on 24-hour feeding pattern. A : 2-deoxytetronic acid (2-DTA). Top panel, base-line control. Middle panel, icv injection of 2-DTA at open triangle head $(1700 \mathrm{~h})$. Bottom panel, posttest control. Three successive days. Each upper trace, locomotor activity and number of crossings per hour of 9 points on rat cage floor. Middle trace (upward deflection), number of pellets eaten. Lower trace (downward deflection), number of water droplets drunk. Shaded area, dark phase. Total numbers (nos.) for 24 hours are indicated at right of each trace. B : 3-deoxypentonic acid (3-DPA). Injection $(2.5 \mu \mathrm{mol}$, at open triangle head) at $1400 \mathrm{~h}$. Note that 3DPA elicits and maintains a high level of food intake for several hours.

ニューロンは 2-DTA で脱分極し（膜の電気的抵抗増大） て活動が上昇する。すなわち $\mathrm{K}$-チャンネルの閉塞であ る。2-DTA はブドウ糖感受性ニューロンに対して膜の 過分極を引き起こし(膜の電気的抵抗, 不変) ニューロ ン活動は低下寸る。すなわち膜の $\mathrm{Na}-\mathrm{K}$ ATP ase の 活性 を高めたことになる。これらの両ニューロンに対する 2-DTA の作用はブドウ糖のそれと完全に同じである。

3-DPA はブドウ糖受容ニューロンを抑制し，ブドウ 糖感受性ニューロン活動を上昇させる。前者の抑制作用 は過分極によるもので膜の電気的抵抗は低下している。

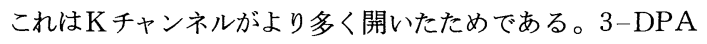
のブドウ糖感受性ニューロンに対しては活動増大である。 この増大機序はまだ解析できていない。

5. 1. 3. 末梢投与作用 以上のことから 2-DTA と 3-DPA はそれぞれ満腹および空腹物質と呼ぶことがで きる。2-DTA はラット頸動脈から注入すると，2,500 $\mu \mathrm{mol}$ という第 3 脳室内投与の 1,000 倍の大量ではじめ て摄食抑制効果を発揮する。これは 2-DTA が毛細血管
壁に付着したりして, 有効濃度が VMH や LHA に到達 しないことを示している。3-DPA は 100 倍の $250 \mu \mathrm{mol}$ を腹腔内投与や静脈内注射で充分捸食を誘起し, また 量-作用的に摂食量を増加させる。2-DTA や 3-DPA は正常血中では $\beta$-アルブミンや他のリポプロティンなど と結合した状態で運搬されているのであろう。血液から 抽出段階でこれらがはずれるものと考えられる。3-DPA の脳への到達は恐らくC数が増えて脂肪溶解性が増加し たためであろう。

5. 1. 3. 1. リポゾーム法 $\quad 1,200 \mu \mathrm{mol} \sim 2,500 \mu \mathrm{mol} \mathrm{2-}$ DTA をリポゾームにつつみ込んだものを消灯時腹腔内 に注入すると対照に比し 3 時間で攝食量は約 $1 / 2$ に減少 する(図5)。リポゾーム法はレシチン：コレステロー ル：スルハチド $=4: 4: 2$ の比で混合してクロロホル ムに溶解し, クロロホルムを蒸発させた後 2-DTA を入 れて超音波でかくはんする。2-DTA の $8 \%$ がリポゾー ムにつつみこまれ，その 2-DTA の $1 \%$ が脳に達すると いわれている。これから計算すると, 約 $1 \mu \mathrm{mol} \sim 2 \mu \mathrm{mol}$ 

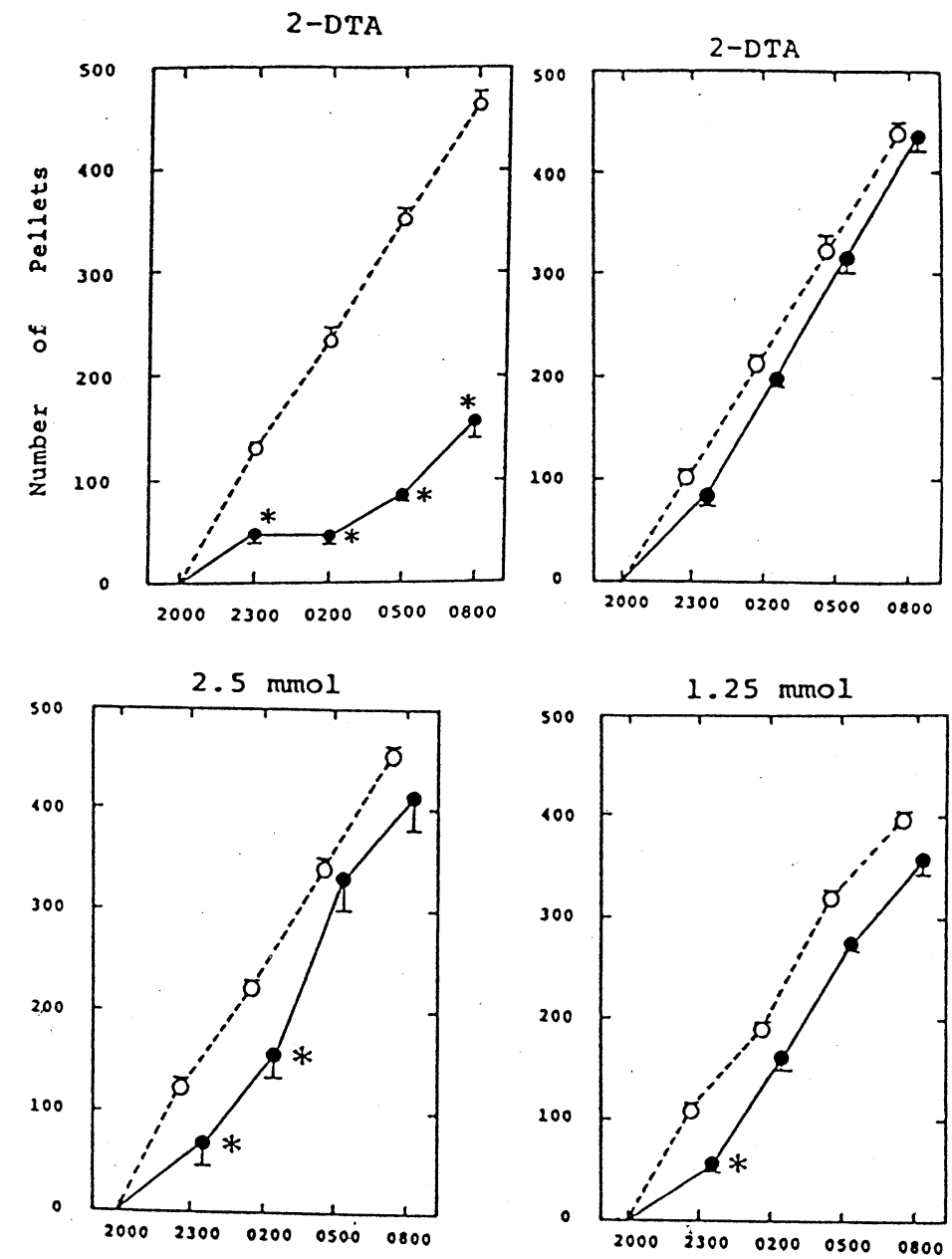

Fig. 5 Effect of 2-DTA. Upper left : Consecutive 3 hour cumulative food consumption during the 12 hour dark period for to administration of phosphate buffer solution (PBS, open circles) and $2.5 \mu \mathrm{mol} 2$-DTA (closed circles) into the rat third cerebroventricle. Note that 2-DTA decreases food intake throughout the 12 hour dark period. Upper right : No effect of intraperitoneal injection of $2.5 \mathrm{mmol} 2$-DTA. Lower : Dose-related feeding suppression induced by encapsulated 2-DTA with liposomes. Intraperitoneal injection of $2.5 \mathrm{mmol}$ (left) and $1.25 \mathrm{mmol}$ (right) 2-DTA liposomes shows suppressive effect on feeding. PBS liposomes (open circles), no effect.

が脳での有効量になる ${ }^{4)}$ 。

5. 1. 3. 2. 化学誘導体 2-DTA の形をかえて脳に到 達させるため 2-buten-4-olideを合成し, 腹腔内や<smiles>O=C1C=CCO1</smiles>

2-buten-4-olide
脳室内に投与してみた。図 6 に示すように $50 \mathrm{mg} / \mathrm{kg}$ お よび $100 \mathrm{mg} / \mathrm{kg}$ と投与量を増加すると，24 時間摂食量 が $10 \%$ と $43 \%$ それぞれ減少し翌日には回復してい る。第 3 脳室投与では $1 / 100 \sim 1 / 200$ で充分である。

5.1.4. 起原と代謝経路 2-DTA および 3-DPAの 起原や代謝経路については，まだ不明の点が多い。ヒトに $S$ 型 2-DTA を投与するとそれ以上の 2-DTA が尿中に 

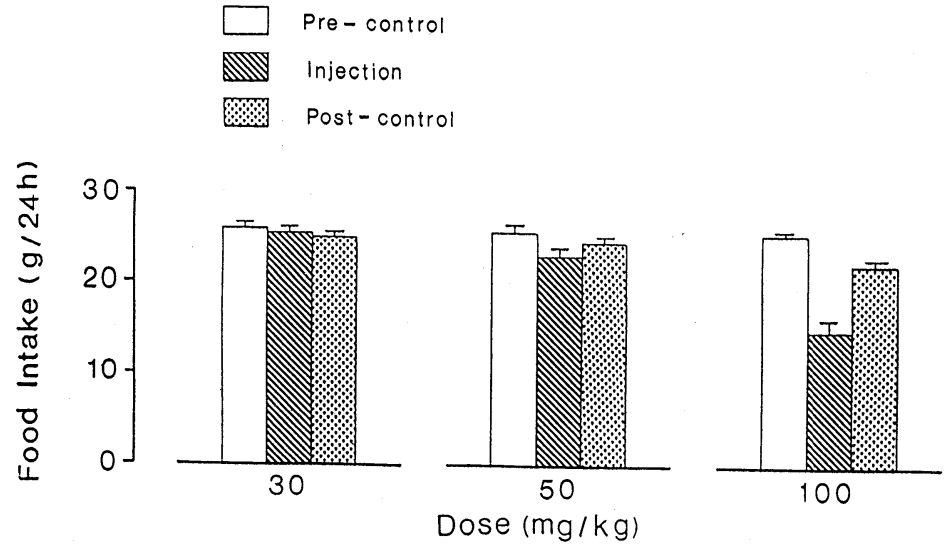

Fig. 6 Suppressive effect of 2-DTA derivative on food intake. Comparison of amount of food taken for 24 hours. Intraperitoneal injection of 2 -buten-4-olide at 2 hours before dark $(2000 \mathrm{~h})$.

現われること, 含水炭素を多く与えると尿中に多く現わ れることなどから，何らかの代謝物である。グルタミン 酸の代謝産物の一つである 4-hydroxybutyrate が $\beta$-酸 化の過程で中間産物の 2-DTA が出てくる可能性がある。 それは 4-hydroxybutyrate と 2-DTA の中間物を名大 医学部の丹羽らが GC/MS で見出したからである。

$$
\begin{aligned}
& \stackrel{\mathrm{OH}}{\stackrel{\mathrm{I}}{\mathrm{C}} \mathrm{H}_{2}-\mathrm{CH}_{2}-\mathrm{CH}_{2}-\mathrm{COOH} \rightarrow \stackrel{\mathrm{OH}}{\mathrm{C}} \mathrm{H}_{2}-\mathrm{CH}=\mathrm{CH}-\mathrm{COOH}} \\
& \text { 4-hydroxybutyric 4-hydroxy-2,3- } \\
& \text { acid } \\
& \stackrel{\mathrm{OH}}{\mathrm{I}} \underset{\mathrm{I}}{\stackrel{\mathrm{I}}{\mathrm{C}} \mathrm{H}_{2}-\mathrm{CH}}-\mathrm{CH}_{2}-\mathrm{COOH} \rightarrow \stackrel{\mathrm{OH}}{\stackrel{\mathrm{C}}{\mathrm{C}} \mathrm{H}_{2}-\mathrm{CO}-\mathrm{CH}_{2}-\mathrm{COOH}} \\
& \text { 3,4-dihydroxy } \\
& \text { butyric acid } \\
& \text { 3-keto-4-hydroxy }
\end{aligned}
$$

3-DPA に関しては ${ }^{13} \mathrm{C}$-ブドウ糖掞よび $\mathrm{D}_{3}$-醋酸か ら由来の可能性があるが，今後決定しなければならない。 2-DTA および 3-DPA が脳内でも産生されて作用し ているのか，VMH や LHA にはどの程度の密度で結合 するのか，ニューロンに取り込まれて代謝されるのかな ど今後明らかにすべき点も多い。

5. 1.5. ケトン体 3-hydroxybutyric acid (3-HBA) はFFA とともに絶食時にはブドウ糖の代りにニューロ ンでエネルギー源として消費される。糖尿病の患者で含 水炭素の代謝の低下から血中にケトン体が増加すると強 い食欲不振が起こってくる。3-HBAを $1.2 \sim 2.5 \mu \mathrm{mol}$ 第 3 脳室内に昼間投与すると, 約 10 分後に 1 回量の摄 食をした後, 夜間の提食量が $1 / 2$ 以下に低下してしまう。 歩行量は夜間わずかに低下するが，これは脳の一般的抑
制のためではない。それは 3-HBA もVMH と LHA の ニューロンにしか作用しないからである。多連微小電極 法で作用させると VMH のブドウ糖ニューロンにだけ 3HBA は効果があり活動上昇である。この上䄯はブドウ

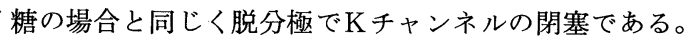
LHA ではブドウ糖感受性ニューロンにだけ 3-HBA は作 用しこれも活動上昇である。この作用機構はまだ明らか にしていない。

摂食行動では一時的の摂食誘起とその後の強い抑制で あるが，長期にわたってLHA の単一ニューロン活動を 記録してみると, 前者の誘起とはうまく一致して活動上 昇が起こっている。そしてその後の捸食抑制に相当して のニューロン活動の抑制が見られない。ブドウ糖受容 ニューロンの 3-HBA に対する反応のようにおそらく VMH の活動上昇が強く作用するために捸食抑制がくる と考えられるが, より詳細な実験を必要とする。

3-HBA も腹腔内投与や静脈内注射では無効である。 やはり脂溶性を増加するため形をかえ下記のように $3-n-$ butyryloxybutyric acid とすると有効になる。

$$
\begin{gathered}
\mathrm{OCO}(\mathrm{CH})_{2} \mathrm{CH}_{3} \\
\mathrm{CH}_{3}-\mathrm{CH}-\mathrm{CH}_{2}-\mathrm{COOH}
\end{gathered}
$$

5. 1. 6. 類似有機酸 2-DTA，3-DTA 抢よび3DPA をラクトン環を開いてみると次のようである。

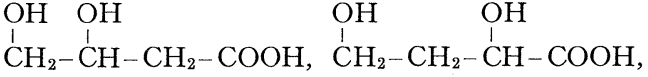

$$
\begin{aligned}
& \text { 2-DTA 3-DTA }
\end{aligned}
$$


<smiles>O=C(O)C(O)CC(O)CO</smiles>

2-DTA の満腹物質の作用と，3-DTA と 3-DPA の 空腹物質としての作用の差異は 2 番目と 3 番目のCに $\mathrm{OH}$ があるかないかである。3-HBA の満腹物質として

$$
\begin{array}{ccc}
\stackrel{\mathrm{OH}}{I} & \stackrel{\mathrm{OH}}{\mathrm{I}} & \stackrel{\mathrm{OH}}{\mathrm{H}} \\
\mathrm{CH}_{3}-\mathrm{CH}-\mathrm{CH}_{2}-\mathrm{COOH}, & \mathrm{CH}_{3}--\mathrm{CH}-\mathrm{CH}_{2}-\mathrm{CH}_{2} \\
3-\mathrm{HBA} & \text { butanediol }
\end{array}
$$

の効果も 2 番目の $\mathrm{OH}$ の欠如である。宇宙食の防腐剤と して butanediol が用いられていた。宇宙旅行時の食欲不 振の原因の一つは無重力による LHA ニューロン活動 の変化であるが, 他は butanediol の血糖値を変化させる ことと撜食抑制作用 ${ }^{5}$ でこれも 2 番目の $\mathrm{OH}$ を欠いてい る。合成した 2-DPA も摄食抑制作用をもっている。

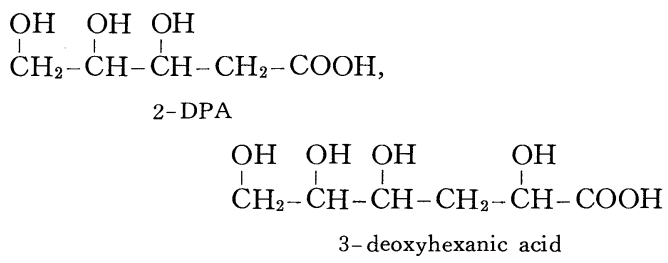

3-deoxyhexanic acid の効果はまだ未定である。

\section{6. 未来への希望}

末梢臟器や脳内のペプチド，ホルモン，代謝産物，さ
らに，短炭鎖の有機酸など内在性の体液性成分が，満腹 中枢のブドウ糖受容ニューロンと摂食中枢のブドウ糖感 受性ニューロンという 2 群に作用して, 満腹感や空腹感 を形成するもとをつくっている。これら 2 群のニューロ ンはこのようにマルチチャンネルの情報処理能力をもっ て血液化学情報分析の役割をおっている。これらを作動 させる化学情報はまだまだ発掘できるはずである。これ ら一連の実験で痛切に感じたことは, 神経生理学, 生化 学, 有機化学, 薬学などの密接な連携である。日本の学 問とその応用の発展が我が国の将来を左右することを考 えると, 学際的な協力研究が非常に大切であることを痛 感する。

（昭和 60 年 9 月 25 日受理）

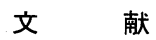

1) M. J. Shuster, J. S. Camardo, S. A. Siegelbaum, E. R. Kandel, Nature, 313, 392 (1985)

2) N.Shimizu, Y. Oomura, T. Sakata, Am. J. Physiol., 246, 542 (1984)

3) K.P. Puthuraya, Y. Oomura, N. Shimizu, Brain Res., 332, 165 (1985)

4) Y. Nagai, T. Osanai, T. Sakata, K. Arase, Y. Oomura, Medical Application of Liposome (K. Yagi, ed.) Jap. Sci. Soc. Press, Tokyo (1985) in press.

5) R. G. Carpentor, S. P. Grossman, Physiol. Behav., 30, 57 (1983)

\begin{tabular}{|c|c|c|c|c|}
\hline 表 紙 2 & 1 頁 & 60,000 円 & 後 付 & 42,000 円 \\
\hline 紙 & 1 頁 & 50,000 円 & " $1 / 2$ 頁 & 22,000 円 \\
\hline 表 紙 & 1 頁 ( 2 色) & 80,000 円 & 緅 込 (1 枚) & 80,000 円現物持込 \\
\hline 英文目次 & 2 頁 & 25,000 円 & & \\
\hline
\end{tabular}

\section{本 誌広 告 料 金}

詳細は下記一手取り扱い社へご照会下さい。

（株）共 栄 通 信 社

本 社 104 東京都中央区銀座 8-2-1（新田ビル） Tel. 03-572-3381（代）

大阪支社 530 大阪市北区西天満 3-6-8（笹屋ビル） Tel. 06-362-6515（代） 